\title{
Shelf life of lactic acid bacteria inoculated vacuum packed Tenualosa ilisha (Hamilton, 1822) at low temperature
}

\author{
S. CHOWDHURY, U. RAYCHAUDHURI*, S. NATH AND K. C. DORA \\ Department of Fish Processing Technology, Faculty of Fishery Sciences \\ West Bengal University of Animal and Fishery Sciences, Kolkata - 700 094, West Bengal, India \\ *Department of Food Technology and Biochemical Engineering, Jadavpur University, Kolkata - 700032 \\ West Bengal, India \\ e-mail: supratimchowdhury@yahoo.co.in
}

\begin{abstract}
Lactobacillus pentosus FPTLB13 was used as a biopreservative agent for hilsa steaks (Tenualosa ilisha) in vacuum packs at $5^{\circ} \mathrm{C}$. The inoculated steaks $(\mathrm{T})$ exhibited lowering of $\mathrm{pH}$ from 6.2 to 5.6 on day 12 , probably due to production of organic acids. A sharp increase in total volatile base nitrogen was seen after day 12 of storage in treated steaks which could be attributed to extended lag phase of the spoilage microorganisms as result of competitive inhibition by lactic acid bacteria $(\mathrm{LAB})$ and effect of acidification. Application of LAB cultures seems to have decreased the rate of trimethylamine formation $(\mathrm{p}<0.05)$ in the inoculated steaks at $5^{\circ} \mathrm{C}$ over a period of 15 days. Packing of hilsa steaks in vacuum cuts off oxygen supply and therefore lipid oxidation is reduced. The trend in changes in free fatty acid values of hilsa steaks suggested that application of LAB significantly reduced the values compared to control $(C)(p<0.05)$. Application of LAB do not seem to improve $(\mathrm{p}>0.05)$ the texture and flavour of hilsa steaks, although the scores of overall acceptability suggests a significant improvement $(\mathrm{p}<0.05)$. The inoculated steaks were found to have a shelf life of 12 days under vacuum at $5^{\circ} \mathrm{C}$.
\end{abstract}

Keywords: Biopreservation, Lactic acid bacteria, Lactobacillus pentosus, Tenualosa ilisha, Vacuum packaging

Hilsa (Tenualosa ilisha Hamilton, 1822) forms commercially the most important fishery of the Hooghly estuarine system and the fishery is seasonal in nature (Nath and Banerjee, 2012). Hilsa is a delicacy among the people in West Bengal and Bangladesh and the recent price trends make it one of the costliest fish in the region. Priced at almost US $\$ 12$ to 15 per $\mathrm{kg}$, it is in great demand among the urban population in West Bengal. However, due to the recent dwindling catch of hilsa, the fish has become a rare commodity in West Bengal households (Mohanty et al., 2011). This has resulted in import of the species from Bangladesh and other coastal states of India. As such the fish is prone to quality problems, resulting from lack of proper preservation techniques, improper packaging and icing. Fish meat is highly perishable, as it contains protein, polyunsaturated fatty acids, natural enzymes and low stroma protein with higher digestibility (Sudalayandi and Manja, 2011). Natural enzymes present in the fish generate autolytic changes, which produce amines, amino acids and glucose for bacterial growth. Bacteria convert the nitrogenous compounds, such as ammonia, aldehyde, hydrogen sulphide and indole, into various other derivatives under putrefaction (Sudalayandi and Manja, 2011). Most of the marine fishes contain a non-protein nitrogenous substance called trimethylamine oxide (TMAO). Certain bacteria, that occur naturally on the skin and gut of fish and in seawater, can break down TMAO to trimethylamine (TMA) (Brettar et al., 2002). Significant deterioration of sensory quality and loss of nutritional value have been detected, as a result of changes in the protein and lipid fractions, formation of amines (volatile and biogenic) and hypoxanthine, and changes in the physical properties of the muscle (Aubourg, 2001). Such biochemical changes are undesirable and require application of several preservation techniques, including use of preservatives.

Considering the high price of hilsa, it is obvious that the consumer will prefer good quality, minimal freeze damage, more natural (free of artificial additives) and safer product (Stiles, 1996). Therefore, to satisfy the trend in consumer demands for hilsa, with less chemical preservatives and at the same time with enhanced safety and quality, it is felt necessary to develop chill stored, minimally processed, hygienic and attractively packed fish steaks.

The use of lactic acid bacteria (LAB) in combination with mild physicochemical treatments and low concentrations of traditional and natural chemical preservatives may be an efficient way of extending shelf 
life and food safety through the inhibition of spoilage and pathogenic bacteria without altering the nutritional quality of raw materials and food products (Bartels and Matser, 2004). The process of extension of shelf life and food safety by the use of natural or controlled microbiota and/or their antimicrobial compounds is referred to as biopreservation. One of the most common forms of food biopreservation is fermentation, a process based on the growth of microorganisms in foods, whether natural or added.

Several food grade lactic acid bacteria, used in food fermentation, are known to have antimicrobial properties. LAB produce lactic acid or lactic and acetic acids, and they may produce other inhibitory substances, such as diacetyl, hydrogen peroxide, reuterin ( $ß$-hydroxypropionaldehyde) and bacteriocins (Stiles, 1996). Since cells and metabolites of these bacteria have been consumed through different fermented foods for thousands of years without any health hazard, it was assumed that the use of these antimicrobial metabolites of LAB can be approved by the regulatory agencies. LAB that grow as the adventitious microflora of foods or that are added to foods as cultures are generally considered to be harmless or even as advantageous for human health (probiotics) (Naidu et al., 1999). In United States, LAB is given 'Generally Regarded as Safe (GRAS)' status (Osmanoglu and Beyatli, 2001). Some of the metabolites of the LAB and other starter culture bacteria have already been permitted for use in foods as food additives. The bacteriocin, nisin of Lactococcus lactis, have been approved as an antimicrobial biopreservative for use in some foods, particularly some dairy foods in many countries.

The use of vacuum packaging is expected to make hilsa steaks more attractive, safe and convenient for consumers and at the same time improve shelf life. Plaatjies et al. (2004) opined that vacuum packaging renders food safe from microorganisms, biological and chemical changes, so that packaged foods may have a longer shelf life. In anaerobic conditions of a vacuum pack, potent spoilage bacteria are severely or totally inhibited at low $\mathrm{pH}$ $(<5.8)$. However, in food products having high muscle $\mathrm{pH}$ spoilage bacteria will cause relatively rapid deterioration of food in vacuum pack. Vacuum packaging is now commonly used worldwide for long term preservation and storage of fresh, dried and frozen foods. Hilsa steaks packed in vacuum can conveniently be distributed around the globe, irrespective of the season of catch and distance of fishing grounds. The present investigation is therefore aimed at assessing the shelf life of LAB inoculated hilsa steaks packed in vacuum and stored at $5^{\circ} \mathrm{C}$.

Lactic acid bacteria, Lactobacillus pentosus FPTLB13, isolated from freshwater fish, mrigala
(Cirrhinus mrigala) was procured from the culture collection of Department of Fish Processing Technology, Faculty of Fishery Sciences, Kolkata. The LAB strain was reported to produce bacteriocin like substances that has spectrum of antimicrobial activity against Lactobacillus casei MTCC 1423, Lactobacillus sakei ATCC 15521, Staphylococcus aureus ATCC 25923, Pseudomonas aeruginosa MTCC 3163, Escherichia coli MTCC 1563 and Enterococcus faecalis MTCC 2729 (Chowdhury et al., 2010). The Gram-positive, catalase negative L. pentosus FPTLB13 was identified based on carbohydrate fermentation pattern using API 50CHL test kit (Biomerieux, France) (Chowdhury et al., 2010). For inoculation of hilsa steaks with L. pentosus FPTLB13, concentrated broth culture was prepared in modified de Man Rogosa Sharpe (MRSm) broth [MRS media containing $0.1 \%(\mathrm{w} / \mathrm{v})$ glucose and supplemented with $50 \mu \mathrm{g} \mathrm{ml}^{-1}$ of cycloheximide (Hi-media, India) and $100 \mathrm{IU} \mathrm{ml}^{-1}$ of polymixin B (Hi-media, India)].

Samples of hilsa (Tenualosa ilisha) caught from Hooghly Matlah Estuary, with an average weight of $800 \pm 20 \mathrm{~g}$, were procured from local market (Kolkata) and brought to the laboratory in iced condition within $4 \mathrm{~h}$ of catch. Steaks were cut from the fish under hygienic and sanitary conditions, to prevent any cross contamination. Cubes were randomly cut from the steaks of hilsa, such that the final weight of each piece was approximately $40 \mathrm{~g}$. For preparation of culture, the isolated LAB strain was grown in MRSm broth, under anaerobic conditions, in order to avoid $\mathrm{H}_{2} \mathrm{O}_{2}$ formation, up to stationary phase $\left(48 \mathrm{~h}\right.$ at $\left.30^{\circ} \mathrm{C}\right)$. The LAB cells were then harvested by centrifugation for $5 \mathrm{~min}$ at $5000 \mathrm{rpm}$ at room temperature and resuspended in sterile distilled water and density of cells was determined using McFarland standard. The cells were then surface inoculated using a dropper, on the cube samples (T) at a level of approximately $1 \times 10^{7} \mathrm{CFU} \mathrm{m}{ }^{-1}$. Excess fluid was drained into a sterile container and the samples were allowed to dry in air at room temperature for 15 min under a laminar flow hood to allow cells to attach. The cubes were then vacuum packaged using INDVAC vacuum packaging machine, and stored at $5^{\circ} \mathrm{C}$ as described by Amezquita and Brashears (2002). Control samples (C) were prepared by vacuum packaging the fillets with no LAB cells added. Packaging material used was a NY/LDPE laminated film bag of $15 \times 20 \mathrm{~cm}$ dimensions. All steps involved in preparation of the sample were done in food grade laboratory. The samples were subjected to biochemical and sensory analysis and samples were collected at 3 days interval on $0,3,6,9$ and so on, till the scores crossed the limits of acceptability.

The samples were subjected to biochemical analyses in triplicate. Estimation of trimethylamine-nitrogen 
(TMA-N), total volatile base-nitrogen (TVB-N) and $\mathrm{pH}$ were carried out as described by EIC (1995). Changes in free fatty acids (FFA) and peroxide value (PV) were analysed as per Jacobs (1958).

Sensory evaluation of fillets was performed during storage by a sensory panel comprising of 15 experienced members. They were required to evaluate the raw fillets, based on the colour, odour, texture and overall acceptability using a 7 -points hedonic scale: $1=$ dislike very much, $2=$ dislike moderately, $3=$ dislike slightly, $4=$ neither like nor dislike, $5=$ like slightly, $6=$ like moderately and $7=$ like very much (Siah and Tahir, 2011).

All the experiments were carried out in triplicate and the results are shown as mean \pm standard deviation (SD). All data were checked for normal distributions with normality plots prior to analysis of variance (ANOVA), to determine significant differences among means at $\alpha=0.05$ level, using statistical tools of $\mathrm{R}$ software (ver. 2.14.1).

In the presence of $L$. pentosus FPTLB13, in anaerobic (vacuum packaged) condition, hilsa cubes exhibited lowering of $\mathrm{pH}$ value from the initial level of $6.2 \pm 0.05$ to a lowest level of $5.6 \pm 0.11$ on day 12 . In case of control sample (C), an increasing trend in the $\mathrm{pH}$ values was observed, reaching a final value of $8.7 \pm 0.11$ on day 15 . The increase in $\mathrm{pH}$ for control samples may be attributed to the production of volatile base compound by bacterial activity. In treated sample, the gradual lowering in $\mathrm{pH}$ value was seen till 12 days, probably due to production of organic acids by the inoculated LAB species. This was followed by an increase in $\mathrm{pH}$ value to $5.9 \pm 0.15$ on day 15 . The trends in changes of $\mathrm{pH}$ values of LAB inoculated hilsa cubes at $5^{\circ} \mathrm{C}$ (Table 1) clearly reveal that the treatment with $\mathrm{LAB}$ resulted in significant lowering of $\mathrm{pH}(\mathrm{p}<0.05)$ value, when compared to control hilsa cubes. This may be due to the spoilage reaction caused by the LAB species after 12 days. Similar observation was reported by Sudalayandi and Manja (2011) for Lactobacillus plantarum treated Indian mackerel chunks.

For the control samples (C), the TVB-N values were within the acceptable limit of $35 \mathrm{mg} \%$ till 12 days
(32.87 $\pm 0.42 \mathrm{mg} \%$ ), as suggested by Laksmanan (2000). In case of hilsa treated with LAB culture and stored anaerobically at $5^{\circ} \mathrm{C}$, the changes were significantly lower $(p<0.05)$ compared to the control samples (Table 1$)$. The final TVB $-\mathrm{N}$ content at the end of 15 days storage was $29.29 \pm 0.25 \mathrm{mg} \%$ for L. pentosus FPTLB13 treated hilsa samples.

According to Ndaw et al. (2008), the increase in TVB-N values are attributed to autolytic enzymes and deamination, which lead to the formation of several volatile compounds, like dimethylamine, trimethylamine, ammonia, TMAO, hypoxanthine and non-volatiles like histamine, which are produced by both bacterial and endogenous enzymes (Ruiz-Capillas and Moral, 2005). In the treated samples (T), the values of TVB-N were within the limit of acceptance till 15 days, which may be attributed to extended lag phase of the spoilage microorganisms as result for competitive inhibition by $\mathrm{LAB}$ and at the same time effect of LAB acidification (Aubourg et al., 2002). Ibrahim and Salha (2009) reported that the combined coating of lactic acid bacteria in tilapia fillets had decreased TVB-N values. Sudalayandi and Manja (2011), observed that, out of seven LAB tested for quality indices reduction, Lactobacillus helveticus, Lactococcus lactis and Pediococcus acidilactici successfully controlled TVB-N. Vacuum packaging together with low temperature preservation is also reported to have the ability to inhibit the growth of spoilage bacteria (Gaussault and Leveau, 2006). From the results it may thus be concluded that the treatment of hilsa with L. pentosus FPTLB13, under vacuum at $5^{\circ} \mathrm{C}$, resulted in significant $(\mathrm{p}<0.05)$ reduction of TVBN levels.

Spoilage bacteria, such as Shewanella putrefaciens, Photobacterium phosphoreum and Vibrionaceae, are able to utilise TMAO as a terminal electron acceptor in an anaerobic respiration, resulting in the formation of TMA (Dalgaard et al., 1993). Formation of TMA imparts off odour and flavour to fish. Sikorski et al. (1990) reported a TMA value of 5-10 $\mathrm{mgN} 100 \mathrm{~g}^{-1}$ of fish as limit of acceptability. In the present study, an initial TMA level of $2.48 \pm 0.08 \mathrm{mgN} 100 \mathrm{~g}^{-1}$ was observed. This value is higher

Table 1. Changes in biochemical parameters of LAB inoculated vacuum packed hilsa steaks at $5^{\circ} \mathrm{C}$

\begin{tabular}{|c|c|c|c|c|c|c|c|c|c|c|}
\hline \multirow{2}{*}{ Days } & \multicolumn{2}{|c|}{$\mathrm{pH}$} & \multicolumn{2}{|c|}{ TVBN (mg\%) } & \multicolumn{2}{|c|}{ TMAN (mgN $\left.100 \mathrm{~g}^{-1}\right)$} & \multicolumn{2}{|c|}{$\mathrm{PV}$ (milliequivalent of $\mathrm{O}_{2} \mathrm{~kg}^{-1}$ ) } & \multicolumn{2}{|c|}{ FFA ( $\%$ of oleic acid $)$} \\
\hline & $\mathrm{C}$ & $\mathrm{T}$ & $\mathrm{C}$ & $\mathrm{T}$ & $\mathrm{C}$ & $\mathrm{T}$ & $\mathrm{C}$ & $\mathrm{T}$ & $\mathrm{C}$ & $\mathrm{T}$ \\
\hline 0 & $6.2 \pm 0.05^{\mathrm{abc}}$ & $6.2 \pm 0.05^{\mathrm{abc}}$ & $4.57 \pm 0.15^{\mathrm{a}}$ & $4.57 \pm 0.15^{\mathrm{a}}$ & $2.48 \pm 0.08^{\mathrm{a}}$ & $2.48 \pm 0.08^{\mathrm{a}}$ & $2.13 \pm 0.02^{\mathrm{a}}$ & $2.13 \pm 0.02^{\mathrm{a}}$ & $1.63 \pm 0.10^{\mathrm{a}}$ & $1.63 \pm 0.10^{\mathrm{a}}$ \\
\hline 3 & $6.4 \pm 0.10^{\mathrm{bc}}$ & $6.2 \pm 0.05 \mathrm{abc}$ & $11.01 \pm 0.30^{\mathrm{bc}}$ & $8.57 \pm 0.35^{\mathrm{b}}$ & $4.00 \pm 0.14^{\mathrm{ab}}$ & $3.88 \pm 0.20^{\mathrm{ab}}$ & $8.05 \pm 0.14^{\mathrm{ab}}$ & $5.73 \pm 0.17^{\mathrm{ab}}$ & $1.88 \pm 0.15^{\mathrm{ab}}$ & $1.68 \pm 0.22^{\mathrm{a}}$ \\
\hline 6 & $6.8 \pm 0.1^{\mathrm{cd}}$ & $6.0 \pm 0.10^{\mathrm{ab}}$ & $19.16 \pm 0.25^{\mathrm{d}}$ & $14.32 \pm 0.15^{\mathrm{c}}$ & $4.40 \pm 0.10^{\mathrm{ab}}$ & $3.88 \pm 0.25^{\mathrm{ab}}$ & $14.07 \pm 0.12^{\mathrm{bc}}$ & $9.17 \pm 0.12^{\mathrm{ab}}$ & $2.83 \pm 0.12^{\mathrm{abcd}}$ & $1.84 \pm 0.14^{\mathrm{a}}$ \\
\hline 9 & $7.3 \pm 0.11^{\mathrm{d}}$ & $5.6 \pm 0.05^{\mathrm{a}}$ & $25.11 \pm 0.25^{\text {ef }}$ & $19.84 \pm 0.22^{\mathrm{d}}$ & $5.50 \pm 0.28 \mathrm{abc}$ & $4.22 \pm 0.14^{\mathrm{ab}}$ & $23.12 \pm 0.20^{\text {cde }}$ & $14.08 \pm 0.14^{\mathrm{bc}}$ & $3.11 \pm 0.14^{\mathrm{bcd}}$ & $1.89 \pm 0.26^{\mathrm{ab}}$ \\
\hline 12 & $8.0 \pm 0.05^{\mathrm{e}}$ & $5.6 \pm 0.11^{\mathrm{a}}$ & $32.87 \pm 0.42^{g}$ & $22.76 \pm 0.18^{\mathrm{de}}$ & $9.19 \pm 0.32^{\mathrm{de}}$ & $6.43 \pm 0.17^{\text {bcd }}$ & $32.48 \pm 0.24^{\mathrm{e}}$ & $21.44 \pm 0.20^{\mathrm{cd}}$ & $3.92 \pm 0.24^{\mathrm{de}}$ & $2.58 \pm 0.15^{\mathrm{abc}}$ \\
\hline 15 & $8.7 \pm 0.11^{\mathrm{e}}$ & $5.9 \pm 0.15^{\mathrm{ab}}$ & $43.69 \pm 0.20^{\mathrm{h}}$ & $29.29 \pm 0.25^{\mathrm{f}}$ & $12.20 \pm 0.17^{e}$ & $8.27 \pm 0.10^{\mathrm{cd}}$ & $48.52 \pm 0.28^{f}$ & $29.63 \pm 0.17^{\mathrm{de}}$ & $4.98 \pm 0.08^{\mathrm{e}}$ & $3.67 \pm 0.05^{\mathrm{cd}}$ \\
\hline
\end{tabular}

"Results are mean $\pm S D$, two way ANOVA; Duncan's multiple comparison test

Values bearing different superscripts within the same parameter differ significantly $(p<0.05)$ 
when compared to the level of about $1 \mathrm{mgN} 100 \mathrm{~g}^{-1}$ of fish, as suggested by FAO (1986) for fresh fish. Further lower value of TMA-N $\left(0.81 \pm 0.23 \mathrm{mgN} 100 \mathrm{~g}^{-1}\right)$ was reported by Ndaw et al. (2008) for raw sardine. Higher initial values in the present study may be due to the initiation of spoilage reaction in hilsa samples. This is probably due to the improper icing and packaging prior to procurement of the fish in the present study. TMA reached a maximum value of $12.20 \pm 0.17 \mathrm{mgN} 100 \mathrm{~g}^{-1}$ on day 15 and thus crossing the limit of acceptability of 5-10 mgN $100 \mathrm{~g}^{-1}$ after 12 days of storage at $5^{\circ} \mathrm{C}$ under vacuum. TMA is a volatile compound contributing to the increase in TVBN values (Ruiz-Capillas and Moral, 2005) and consequently has a probable effect on the increase in $\mathrm{pH}$ values. In case of treated samples, a significant lowering of TMA values $(\mathrm{p}<0.05)$ was observed, with the values recorded being $6.43 \pm 0.17 \mathrm{mgN} 100 \mathrm{~g}^{-1}$ on day 12, followed by an increase over the next three days, reaching a value of $8.27 \pm 0.10 \mathrm{mgN} 100 \mathrm{~g}^{-1}$ on day 15 . The application of LAB probably led to inhibition of spoilage bacteria, responsible for TMA formation during the first 12 days.

A major cause of muscle food quality deterioration is lipid oxidation and the associated changes. The lipids of hilsa are characterised by the presence of mono- and polyunsaturated fatty acids, which seem to pose serious problems with lipid oxidation. Auborg et al. (2002) opined that oxidation of unsaturated lipids is highly related to the production of off flavours and odours and also influences protein denaturation and texture changes (Orak and Kayisoglu, 2008). Packing of hilsa steaks in vacuum cuts off oxygen supply and therefore expected to reduce lipid oxidation. In the present study, PV is measured, in order to assess the primary changes in lipid resulting in formation of hydroperoxide, as suggested by Coxon (1987). Lakshmanan (2000) reported that if the PV is above 10-20 milliequivalent of $\mathrm{O}_{2} \mathrm{~kg}^{-1}$ of fat, then the fish will smell and taste rancid in all probability. PV for hilsa steaks packed in vacuum and stored at $5^{\circ} \mathrm{C}$ increased from an initial level of $2.13 \pm 0.02$ to $48.52 \pm 0.28$ milliequivalent of $\mathrm{O}_{2} \mathrm{~kg}^{-1}$ of fat over a period of 15 days. The values for PV crossed the limit of acceptability on day 9 of storage under vacuum at $5^{\circ} \mathrm{C}$. In $\mathrm{LAB}$ treated steaks $(\mathrm{T})$, a significant reduction in $\mathrm{PV}$ value $(\mathrm{p}<0.05)$ was observed. Similar reduction in PV value was reported by Sudalayandi and Manja (2011) while working with $P$. pentasaceous and $P$. acidilactici. For LAB treated samples, PV values crossed the limit of acceptability on day $12\left(21.44 \pm 0.20\right.$ milliequivalent of $\left.\mathrm{O}_{2} \mathrm{~kg}^{-1}\right)$, with a value of $29.63 \pm 0.17$ milliequivalent of $\mathrm{O}_{2} \mathrm{~kg}^{-1}$ recorded on day 15 .

It has been reported that FFA will be produced during initial stages of chilling process (up to day 9 , approximately) as a result of endogenous enzyme (lipase and phospholipases) activity (Pigott and Tucker, 1990, Whittle et al., 1990). Later on, FFA formation will be mostly as a result of bacterial catabolic processes. At the end of storage period of 15 days, FFA values of $4.98 \pm 0.08 \%$ of oleic acid was observed in hilsa steaks. Low values of FFA may be attributed to the low temperature $\left(5^{\circ} \mathrm{C}\right)$ of storage. In LAB treated samples FFA value of $3.67 \pm 0.05 \%$ of oleic acid was observed at the end of day 15. Refsgaard et al. (2000) reported that FFA accumulation has been associated with lack of sensory acceptability. FFA contributes to off flavour and causes textural alteration by complexing with muscle proteins. Aubourg (2001) reported a gradual increase in FFA values in fish fillet over a period of 19 days. Sudalayandi and Manja (2011) reported that, L. plantarum reduced FFA from 9.4 to $6.4 \%$ of oleic acid in Indian mackeral chunks during 2 days storage at $37^{\circ} \mathrm{C}$. The trend in changes in FFA values of hilsa cubes suggested that application of LAB $(\mathrm{T})$ treatment significantly reduced FFA values, as compared to control $(\mathrm{p}<0.05)$.

In the present study, the changes in colour and texture of cubes cut from hilsa steaks were assessed, based on sensory scores. Observations of the colour scores in hilsa cubes suggest non-uniformity in appearance among the treatments and control samples (Fig. 1) $(p<0.05)$. Control hilsa cubes crossed the limit of acceptability $(<4.0)$ after 9 days of storage. The treatment cubes became unacceptable after 12 days of storage at $5^{\circ} \mathrm{C}$. Besides being considered as a good biopreservative agent, the metabolic activity of LAB is known to produce substances responsible for typical spoilage change, making products eventually unfit for human consumption. These changes include formation of sour flavour and off odour, slime formation and discolouration (Schillinger et al., 1996). Schillinger and Lucke (1987) reported that the first changes associated with LAB spoilage in meat is cheesy, sour and acid flavour. Such changes may naturally be accompanied by odour and taste changes with a drop in $\mathrm{pH}$ value from 6.3 to 5.8 . In the present study, the in $\mathrm{pH}$ value dropped to 5.6 on day 12 for treatment (T), although the product was still acceptable. The LAB inoculated hilsa cubes maintained good quality till 12 days, followed by quality deterioration in the form of off odour, slime formation, discolouration and texture softening (Fig. 1). Eagan et al. (1989) reported similar colour changes in meat caused by Lactobacillus sakei strains. Slime formation was also observed in fillets after day 12, which was in conformation with the results by Lyhs et al. (2004). He reported that, an acetic acid preserved fish show slime and gas formation with off odour, which may be because of the production of diacetyl. 


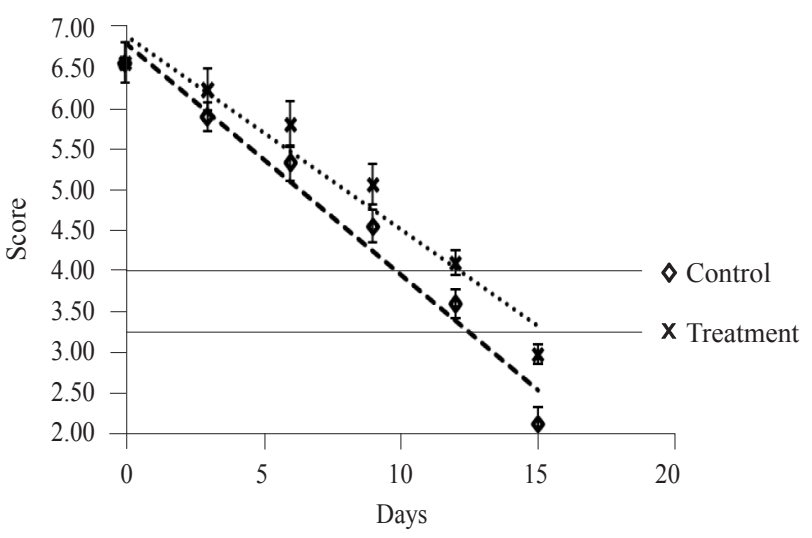

Fig. 1. Changes in overall acceptability of LAB inoculated vacuum packed hilsa steaks at $5^{\circ} \mathrm{C}$, Results are mean $\pm \mathrm{SD}$

Application of LAB did not contribute to any significant ( $p>0.05)$ improvement on texture and flavour of hilsa cubes, when compared to control samples. Korkeala et al. (1989) reported that spoilage changes due to LAB are usually delayed until the stationary growth phase and thus products are expected to retain good sensory qualities for several days. From the study, it may be concluded that the application of test strain significantly improved the overall acceptability of the steaks from 9 to 12 days $(p<0.05)$. After 12 days, LAB behaved as spoilers under anaerobic condition suggesting that spoilage reaction was delayed.

In $\mathrm{LAB}$ treated samples, a lowering of $\mathrm{pH}$ value was observed due to production of organic acids. For treatment sample $(\mathrm{T})$, a sharp increase in TVB-N was seen after day 12 of storage. Application of LAB cultures seems to have decreased the rate of TMA formation in the inoculated cubes of hilsa at $5^{\circ} \mathrm{C}$ over a period of 15 days. The trend in changes in FFA values of hilsa cubes suggested that application of LAB significantly reduced FFA values as compared to control $(\mathrm{p}<0.05)$. Therefore, application of LAB cultures seems to have an influence on several biochemical parameters of hilsa steaks at $5^{\circ} \mathrm{C}$. During the later stages of storage, there seems to be a possibility of LAB to lose its preservative action and it acts as a spoilage organism. This in turn may restrict the application of LAB cultures in the preservation of hilsa steaks. Application of L. pentosus FPTLB13 does not seem to cause any significant $(p>0.05)$ improvement of texture and flavour, although colour and overall acceptability exhibited significant improvement $(\mathrm{p}<0.05)$. The test strains behaved as spoilers under anaerobic condition, which was evident after 12 days of storage. The combined treatment of hilsa steaks with LAB as protective culture in vacuum packs yielded a shelf life of only 12 days at $5^{\circ} \mathrm{C}$. Thus, this strategy may be useful for short term preservation requirements like retail display, satisfying the current trends in consumer demands for minimally processed chilled food products. Lactic acid bacteria have been recognised as safe, and bacteriocins produced by these microorganisms may be a good solution to the problem of resurgence of resistant strains to antibiotics (Parada et al., 2007). LAB as a protective culture is expected to be attractive like the acceptance of probiotics, which aid in digestion and health, by the consumer. However, legal aspects need to be considered for the application of LAB and its bacteriocins, in foods products which needs continued research, as only few have been officially approved for use in food.

\section{Acknowledgements}

The authors are grateful to the Department of Fish Processing Technology, Faculty of Fishery Sciences, WBUA \& FS, Kolkata for providing all necessary facilities to carry out this research work successfully.

\section{References}

Amezquita, A. and Brashears, M. M. 2002. Competitive inhibition of Listeria monocytogenes in ready to eat meat products by lactic acid bacteria. J. Food. Protect., 65(2): 316-325.

Aubourg, S. P. 2001. Damage detection in horse mackerel (Trachurus trachurus) during chilled storage. J. Am. Oil Chem. Soc.,78(8) : 857-858.

Aubourg, S. P., Lehmann, I. and Gallardo, J. M. 2002. Effect of previous chilled storage on rancidity development in frozen horse mackerel (Trachurus trachurus). J. Sci. Food. Agri., 82: 1764-1771.

Bartels, P. and Matser, A. 2004. Novel preservation technologies in relation to food safety. The SAFE Consortium. The future of food safety research in the European Union. Seminar Series 4. Brussels.

Brettar, I., Christen, R. and Hofle, M. G. 2002. Shewanella denitrificans sp. nov., a vigorously denitrifying bacterium isolated from the oxic-anoxicinterface of the Gotland Deep in the Central Baltic Sea. Int. J. Sys. Evol. Microbiol., 52: 2211-2217.

Chowdhury, S., Dora, K. C. and Banerjee, S. P. 2010. Detection, partial purification and characterisation of bacteriocin produced by Lactobacillus pentosus FPTLB13 isolated from freshwater fish. The Asian J. Animal Sci., 5: 2 pp.

Coxon, D. 1987. Measurement of lipid oxidation. Food Sci. Technol. Today, I: 164-166.

Dalgaard, P., Gram, L. and Huss, H. H. 1993. Spoilage and shelf-life of cod fillets packed in vacuum or modified atmospheres. Int. J. Food Microbiol., 26: 319-33.

Eagan, A. F., Shay, B. J. and Rogers, P. J. 1989. Factors affecting the production of hydrogen sulphide by Lactobacillus sake L13 growing on vacuum packaged beef. J. Appl. Bacteriol., 67: $255-262$.

EIC 1995. Manual for analytical methods for fish and fishery products. Quality Development Centre, Ministry of Commerce, Government of India, Madras, India. 
FAO 1986. FAO food and nutrition paper manuals of food quality control food analysis: quality, adulteration and test of identity. Rome: Food and Agriculture Organisation of the United Nations.

Goussault, B. and Leveau, B. 2006. Guide to packaging technology for seafood value addition. Eurofish, Copenhagen, Gdynia, p. 1-20.

Ibrahim, S. M. and Salha, G. D. 2009. Effect of antimicrobial metabolites produced by lactic acid bacteria (LAB) on quality aspects of frozen tilapia (Oreochromis niloticus) fillets. World J. Fish Mar. Sci., 1(1): 40-45.

Jacobs, M. B. 1958. The chemical analysis of food and food products. New York, Krieger Publishing Co. Inc., p. 393-394.

Korkeala, H., Alanko, T., Makfla, P. and Lidroth, S. 1989. Shelf life of vacuum packed cooked ring sausages at different chill temperatures. Int. J. Food. Microbiol., 9: 237-247.

Lakshmanan, P. T. 2000. Fish spoilage and quality assessment. In: Iyer, T. S. G., Kandoran, M. K., Thomas, M. and Mathew, P. T. (Eds.), Assurance in seafood processing. Central Institute of Fisheries Technology, Kochi and Society of Fishery Technologists (India), Kochi, India.

Lyhs, U., Koort, J. M. K., Lundstrom, H. S. and Bjorkroth, K. J. 2004. Leuconostoc gelidum and Leuconostoc gasicomitatum strains dominated the lactic acid bacterium population associated with strong slime formation in an acetic acid herring preserve. Int. J. Food Microbiol., 90: 207-218.

Mohanty, B. P., Das, S., Bhaumik, U. and Sharma, A. P. 2011. Tenualosa ilisha - A rich sorce of omega-3 fatty acids. Bulletin No.171. Central Inland Fisheries Research Institute, Barrackpore, Kolkata.

Naidu, A. S., Bidlack, W. R. and Clemens, R. A. 1999. Probiotics spectra of lactic acid bacteria (LAB). Crit. Rev. Food Sci. Nutri., 39: $13 \mathrm{pp}$.

Nath, A. K. and Banerjee, B. 2012. Comparative evaluation of body composition of hilsa, Tenualosa ilisha (Hamilton, 1822 ) in different size groups with special reference to fatty acid, in Hooghly estuarine system, West Bengal, India. Indian J. Fish., 59(2): 141-146.

Ndaw, A. D., Faid, M., Bouseta, A. and Zinedine, A. 2008. Effect of controlled lactic acid bacteria fermentation on the microbiological and chemical quality of Moroccan sardine (Sardina pilchardus). Int. J. Agri. Biol., 10: 21-27.

Orak, H. H. and Kayisoglu, S. 2008. Quality changes in whole, gutted and filletd three fish species (Gadus euxinus, Mugil cephalus, Engraulis encrasicholus) at frozen storage period $\left(-26^{\circ} \mathrm{C}\right)$. Acta. Sci. Pol. Technol. Aliment, 7: 15-28.
Osmanoglu, O. and Beyatli, Y. 2001. The use of bacteriocins produced by lactic acid bacteria in food biopreservation. Turk. Mikrobiyol. Cem. Derg., 32: 295-306.

Parada, J. L., Caron, C. R., Medeiros, A. B. P. and Soccol, R. C. 2007. Bacteriocins from lactic acid bacteria: Purification, properties and use as biopreservatives. Brazilian Arch. Biol. Technol., 50(3): 521-542.

Pigott, G. and Tucker, B. 1990. Seafood: effects of technology on nutrition. Marcel Dekker Inc., New York, USA, p. 66-84.

Plaatjies, Z., Lues, J. F. R., Buys, E. M. and Venter, P. 2004. Staphylococcal growth in fresh vacuum-packed red meat at various storage conditions. Proceedings: $8^{\text {th }}$ World congress on environmental health, 22-27 February 2004, Document Transformation Technologies, Durban, South Africa.

Refsgaard, H., Brockhoff, P. and Jensen, B. 2000. Free polyunsaturated fatty acids cause taste deterioration of salmon during frozen storage. J. Agri. Food. Chem., 48: 3280-3285.

Ruiz-Capillas, C. and Moral, A. 2005. Sensory and biochemical aspects of quality of whole bigeye tuna (Thunnus obesus) during bulk storage in controlled atmospheres. Food Chem., 89(3): 347-354.

Schillinger, U. and Lucke, F. 1987. Identification of Lactobacilli from meat and meat products. Food Microbiol., 4: 199-208.

Schillinger, U., Geisen, R., Holzapfel, W. H. 1996. Potential of antagonistic microorganisms and bacteriocins for the biological preservation of foods. Trends Food Sci. Technol., 7: 158-164.

Siah, W. M. and Mohd Tahir, S. 2011. Effect of different packaging materials on the shelf life of modified atmosphere packaged red tilapia (Oreochromis mossambica) fillets. Int. Food Res. J., 18(3): 1044-1048.

Sikorski, Z. E., Kolakowska, A. and Burt, J. R. 1990. Post-harvest biochemical and bacterial changes. In: Sikorski, Z. E. (Ed.), Seafood: resources, nutritional composition and preservation. Boca Raton, FL: CRC Press, Inc., p. 55-76.

Sudalayandi, K. and Manja 2011. Efficacy of lactic acid bacteria in the reduction of trimethylamine-nitrogen and related spoilage derivatives of fresh Indian mackerel fish chunks. African J. Biotechnol., 10(1): 42-47.

Stiles, M. E. 1996. Biopreservation by lactic acid bacteria Antonie van Leuwenhoek, 70: 331 pp.

Whittle, K., Hardy, R. and Hobbs, G. 1990. Chilled fish and fishery products In: Gormley, T. (Ed.), Chilled foods: The state of the art. Elsevier Applied Science, New York, USA, p. 87-116. 